\title{
Analisis Kenyamanan Pengguna Koridor Pada Pasar Bandarjaya Plaza
}

\author{
Hadi Hariyanto ${ }^{1^{*}}$ \\ ${ }^{1}$ Mahasiswa, Program Studi Arsitektur, Fakultas Teknik, Universitas Bandar Lampung \\ *Penulis Korespondensi: hadi.16332001p@student.ubl.ac.id; Telp. +62 821-8329-2022
}

\begin{abstract}
Abstrak:
Pasar Bandarjaya Plaza merupakan pasar terbesar di Lampung Tengah. Kurang maksimalnya fungsi koridor yang terdapat pada pasar, mengakibatkan adanya permasalahan di dalam koridor pasar. Keadaan koridor pasar menunjukkan adanya okupansi koridor yang di lakukan oleh pedagang buah dengan asumsi bahwa area koridor merupakan area strategis untuk berjualan. Tujuan dilakukan penelitian tentang tingkat kenyamanan pengguna koridor pasar adalah untuk mendapatkan pengetahuan baru tentang kenyamanan pengguna koridor pada pasar tradisional serta dapat memberikan kontribusi positif kepada arsitek agar membuat koridor sesuai dengan ketentuan. Metode yang dipilih pada pembahasan yaitu metode gabungan yaitu metode kualitatif dan metode kuantitatif yang dilakukan secara berurutan, tahap pertama adalah metode kualitatif, pengumpulan data yang dilakukan melalui wawancara terbuka pada 30 orang responden yang dipilih dengan teknik incidental sampling. Tahap kedua adalah metode kuantitatif, pengumpulan data yang dilakukan adalah dengan cara mendistribusikan kuesioner kepada 100 orang responden. Hasil temuan menunjukkan bahwa tingkat kenyamanan pengguna koridor terhadap okupansi koridor dengan skala rata-rata sebesar 2,5 dari nilai maksimal 4 . Temuan tersebut mengindikasikan bahwa tingkat kenyamanan pengguna koridor pasar rendah dan perlu adanya perbaikan dan peningkatan fasilitas penunjang pada koridor pasar tersebut.
\end{abstract}

Kata Kunci: Kenyamanan, Kepuasan, Koridor, Pasar Tradisional, Bandar Jaya.

\section{Latar Belakang}

Peraturan Presiden RI No. 112 tahun 2007, pasar tradisional adalah pasar yang dibangun dan dikelola oleh Pemerintah, Pemerintah Daerah, Swasta, Badan Usaha Milik Negara dan Badan Usaha Milik Daerah termasuk kerjasama dengan swasta dengan tempat usaha berupa toko, kios, los dan tenda yang dimiliki/ dikelola oleh pedagang kecil, menengah, swadaya masyarakat atau koperasi dengan usaha skala kecil, modal kecil dan dengan proses jual beli barang melalui tawar menawar. Lebih lanjut menurut perpres tersebut, pasar tradisional boleh berlokasi pada setiap sistem jaringan jalan, termasuk jaringan jalan lokal atau jalan lingkungan di dalam kota/kabupaten.

Pasar Bandar Jaya Plaza adalah salah satu fasilitas publik yang berada di Lampung Tengah dan sebagai salah satu penunjang utama dalam bidang perdagangan di Lampung Tengah, perlunya memaksimalkan fungsi Pasar Bandar Jaya Plaza Lampung Tengah dapat menarik minat pengunjung, akan tetapi kurang maksimalnya fungsi yang terdapat pada pasar tersebut mengakibatkan adanya permasalahan di dalam koridor pasar.

Koridor pasar Bandar Jaya Plaza Lampung Tengah saat ini dimanfaatkan sebagai area berjualan oleh pedagang yang menyebabkan sirkulasi pengunjung terganggu. Pedagang berpendapat bahwa area sirkulasi merupakan area yang strategis untuk berjualan.

Keadaan koridor dalam pasar Bandar Jaya Plaza Lampung Tengah yang saat ini dimanfaatkan sebagai area berjualan oleh pedagang menyebabkan terganggunya koridor pengunjung. Hal ini disebabkan oleh pedagang yang berasumsi bahwa area koridor merupakan area yang strategis sebagai penunjang berjualan dengan mengesampingkan penataan ruang yang ada pada pasar Bandar Jaya Plaza Lampung Tengah.

Pasar menurut Kamus Besar Bahasa Indonesia (KBBI) adalah tempat orang berjual beli. Pasar adalah sekumpulan pembeli dan penjual dari sebuah barang atau jasa tertentu. Para pembeli sebagai sebuah kelompok yang menentukan permintaan terhadap produk dan para penjual sebagai kelompok yang menentukan penawara terhadap produk (Mankiew, 2007).

Pasar merupakan seperangkat pembeli aktual dan potensial dari sebuah produk atau jasa. Ukuran dari pasar sendiri tergantung pada jumlah orang yang menunjukkan kebutuhan, memiliki kemampuan dalam pertukaran.

Pasar secara fisik adalah pemusatan beberapa pedagang tetap dan tidak tetap yang terdapat pada suatu ruangan terbuka atau tertutup. Selanjutnya pengelompokan para pedagang tersebut menepati bangunan permanen ataupun semi permanen . 
Pasar adalah tempat perjumpaan antara pembeli dan penjual, dimana barang/jasa atau produk dipertukarkan antara pembeli dan penjual. Ukuran kerelaan dalam pertukaran tersebut biasanya akan muncul suatu tingkat harga atas barang dan jasa yang dipertukarkan tersebut.

Pasar terbentuk dari proses pertemuan sampai terjadinya kesepakatan. Pasar tersebut tidak memperdulikan tempat dan jenis barang. Jadi pasar tidak terbatas pada suatu lokasi.

\subsubsection{Fungsi Pasar}

Pasar memiliki beberapa fungsi utama. Fungsi utama tersebut menurut Sudarman (1989) adalah: (1) Pasar menetapkan nilai. Dalam ekonomi pasar, harga merupakan ukuran nilai. (2)Pasar mengorganisir produksi. Dengan adanya harga- harga faktor produksi di pasar, maka akan mendorong produsen memilih produksi

yang efisien. Pasar mendistribusikan barang. Kemampuan seseorang untuk membeli barang tergantung pada penghasilannya.

\subsubsection{Jenis Pasar}

Menurut cara transaksinya, jenis pasar terbagi menjadi tiga yaitu pasar tradisional, pasar modern dan pasar online.

1. Pasar tradisional

Menurut Peraturan Presiden RI No. 112 tahun 2007, pasar tradisional adalah pasar yang dibangun dan dikelola oleh Pemerintah, Pemerintah Daerah, Swasta, Badan Usaha Milik Negara dan Badan Usaha Milik Daerah termasuk kerjasama dengan swasta dengan tempat usaha berupa toko, kios, los dan tenda yang dimiliki/ dikelola oleh pedagang kecil, menengah, swadaya masyarakat atau koperasi dengan usaha skala kecil, modal kecil dan dengan proses jual beli barang melalui tawar menawar. Lebih lanjut menurut perpres tersebut, pasar tradisional boleh berlokasi pada setiap sistem jaringan jalan, termasuk jaringan jalan lokal atau jalan lingkungan di dalam kota/kabupaten.

Pasar tradisional adalah pasar yang dikelola dengan cara lebih tadisional dan lebih simpel daripada pasar modern. Umumnya pasar tradisional terdapat di pinggir jalan atau di lingkungan perumahan (Sinaga, 2004).

\section{2. $\quad$ Pasar Modern}

Merupakan tempat bertemunya penjual dan pembeli yang ditandai dengan adanya transaksi jual beli secara tidak langsung. Pembeli hanya melihat label harga pada suatu kemasan produk dan pembelinya dilayani secara mandiri oleh pramuniaga contohnya supermarket dan minimarket

\section{Online Shop}

Online shop adalah suatu proses pembelian barang atau jasa dari mereka yang menjual melalui internet tanpa harus bertatap muka dengan penjual atau pihak secara langsung. Online shop adalah proses dimana konsumen secara langsung membeli barang dan atau jasa dari seorang penjual secara interaktif melalui internet (Mujiyana dan Elissa, 2013). Pengertian online shop

adalah proses jual beli barang, jasa dan lain-lain yang dilakukan secara online tanpa harus bertemu dahulu antara penjual dan pembeli.

\subsection{Tinjauan Khusus}

\subsubsection{Pengertian Pasar Tradisional}

Pasar Tradisional adalah pasar yang dibangun dan dikelola oleh Pemerintah, Pemerintah Daerah, Swasta, Badan Usaha Milik Negara dan Badan Usaha Milik Daerah termasuk kerjasama dengan swasta dengan tempat usaha berupa toko, kios, los dan tenda yang dimiliki/ dikelola oleh pedagang kecil, menengah, swadaya masyarakat atau koperasi dengan usaha skala kecil, modal kecil dan dengan proses jual beli barang melalui tawar menawar (Peraturan Menteri Perdagangan Republik Indonesia, 2013).

Pasar tradisional adalah bentuk paling awal dari pasar yang terdiri dari deretan stan atau kios yang berada di ruang terbuka dan pada umumnya terletak di sepanjang jalan utama dekat permukiman penduduk. Sejak dahulu para pedagang dan petani sudah melakukan pertukaran hasil pertanian mereka di tempat seperti ini (Gallion, 1986).

Pasar tradisional adalah sebuah tempat terbuka yang terjadi proses transaksi jual beli dengan proses tawar menawar. Pasar tradisional ini para pengunjung tidak selalu menjadi pembeli karena bisa menjadi penjual (Sadilah dkk, 2011).

\subsubsection{Ciri-ciri Pasar Tradisional}

1. Pasar tradisional dimiliki, dibangun dan dikelola oleh pemerintah daerah.

2. Adanya sistem tawar menawar antara penjual dan pembeli. 
3. Tempat usaha beragam dan menyatu dalam lokasi yang sama.

4. Sebagian besar barang yang ditawarkan berbahan lokal.

Dari berbagai ciri-ciri diatas, Pasar Plaza Bandar Jaya Lampung Tengah memenuhi ciri-ciri pasar tradisional yang telah ditentukan oleh menteri perdagangan Indonesia. Lahan dan bangunan dikelola oleh pemerintah daerah Kabupaten Lampung Tengah.

\subsubsection{Komponen Pasar Tradisional}

1. Pedagang

Pedagang pasar adalah orang atau badan yang melakukan kegiatan dengan menjual barang dan menggunakan pasar sebagai tempat kegiatannya.

2. Pembeli

Pembeli atau konsumen pasar adalah semua golongan yang datang dengan tujuan untuk mendapatkan apa yang menjadi kebutuhannya dengan harga murah dan dengan pelayanan langsung.

\subsection{Kenyamanan}

\subsubsection{Pengertian kenyamanan}

Kenyamanan menurut Kamus Besar Bahasa Indonesia (KBBI) adalah suatu keadaan yang nyaman. Kenyamanan merupakan suatu kondisi perasaan, dan kondisi perasaan itu sangat tergantung pada orang yang mengalami situasi tersebut. Kita tidak dapat mengetahui tingkat kenyamanan yang dirasakan orang lain secara langsung maupun dengan melakukan pengamatan luar terhadap orang tersebut, tetapi untuk mengetahuinya harus menanyakan langsung kepada orang tersebut mengenai seberapa nyaman diri mereka, dan biasanya menggunakan istilah yang kontinu, seperti agak tidak nyaman, mengganggu, sangat tidak nyaman hingga mengkhawatirkan (McCormick dan Sanders, 1987).

Kenyamanan dan perasaan nyaman adalah penilaian seseorang terhadap lingkungannya. Manusia menilai kondisi lingkungan berdasarkan rangsangan yang masuk ke dalam dirinya melalui keenam indera melalui syaraf dan dicerna oleh otak untuk dinilai (Satwiko, 2009).

Kenyamanan ditentukan oleh beberapa unsur pembentuk dalam perancangan yakni sirkulasi, iklim, kebisingan, aroma/bau-bauan, bentuk, keamanan, kebersihan, keindahan dan penerangan (Hakim, 2003). Sehingga dapat disimpulkan jika kenyamanan adalah kondisi saat terpenuhinya kebutuhan dasar sehingga tercipta perasaan nyaman.

\section{Metode}

Metode penelitian yang digunakan untuk mengetahui tingkat kenyamanan dan kepuasan pengguna koridor pada Pasar Tradisional Bandar Jaya Plaza Lampung Tengah adalah metode penelitian gabungan secara berurutan, yaitu langkah penelitian dengan menggunakan dua bentuk metode penelitian, yaitu kualitatif dan kuantitatif secara berurutan (Creswell, 2003). Metode Gabungan yaitu metode kualitatif dan metode kuantitatif yang dilakukan secara berurutan digunakan untuk melakukan analisis terhadap kenyamanan dan kepuasan pengguna sirkulasi pada bangunan pasar tradisional. Tahap pertama menggunakan metode kualitatif, pengumpulan data dilakukan dengan wawancara. Tahap kedua menggunakan metode kuantitatif, pengumpulan data dilakukan dengan mendistribusikan kuesioner.

\subsection{Metode Pengumpulan Data}

Metode pengumpulan data kualitatif dilakukan dengan kuesioner terbuka (Nazir, 2013). Kuesioner terbuka adalah kuesioner yang diberikan kepada responden yang diberikan kebebasan dalam menjawab. Responden dari kuesioner adalah sebanyak 30 orang yang dipilih secara incidental sampling. Pengumpulan data ini dilakukan pada tanggal 25 November 2018 dan 1 Desember 2018 Di Bandar Jaya Plaza Lampung Tengah dengan pertanyaan terbuka sebagai berikut:

- $\quad$ Apakah anda nyaman dengan koridor pasar ini?

- Kenapa nyaman/tidak nyaman?

- Apa ada yang lain selain yang disebutkan tadi?

- Agar tambah nyaman harus bagaimana? 
Tabel 1. 1 Data Wawancara

\begin{tabular}{|c|c|c|c|c|c|c|c|c|c|c|c|}
\hline \multirow[b]{2}{*}{ 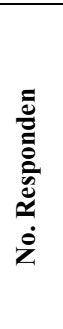 } & \multicolumn{4}{|c|}{ Kenyamanan } & \multicolumn{4}{|c|}{ Alasan } & \multirow[b]{2}{*}{ 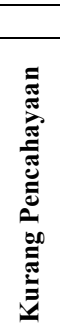 } & \multirow[b]{2}{*}{ 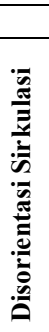 } & \multirow[b]{2}{*}{ 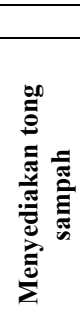 } \\
\hline & $\approx$ & 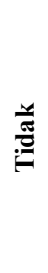 & 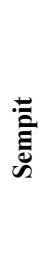 & $\frac{\vec{\theta}}{a}$ & 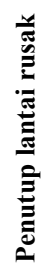 & 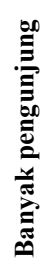 & 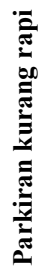 & 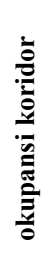 & & & \\
\hline 1 & 0 & 1 & 1 & 0 & 0 & 0 & 0 & 1 & 0 & 0 & 0 \\
\hline 2 & 0 & 1 & 1 & 0 & 0 & 0 & 1 & 0 & 0 & 0 & 0 \\
\hline 3 & 1 & 0 & 0 & 0 & 0 & 1 & 0 & 0 & 0 & 0 & 0 \\
\hline 4 & 0 & 1 & 1 & 1 & 1 & 0 & 0 & 0 & 1 & 0 & 0 \\
\hline 5 & 0 & 1 & 1 & 0 & 0 & 0 & 0 & 0 & 0 & 1 & 0 \\
\hline 6 & 0 & 1 & 1 & 0 & 0 & 0 & 0 & 1 & 0 & 0 & 0 \\
\hline 7 & 0 & 1 & 0 & 1 & 1 & 0 & 0 & 0 & 0 & 0 & 0 \\
\hline 8 & 0 & 1 & 0 & 1 & 0 & 0 & 0 & 0 & 0 & 0 & 0 \\
\hline 9 & 0 & 1 & 1 & 0 & 0 & 0 & 0 & 0 & 0 & 0 & 0 \\
\hline 10 & 0 & 1 & 1 & 0 & 0 & 0 & 0 & 1 & 0 & 0 & 0 \\
\hline 11 & 0 & 1 & 0 & 0 & 0 & 0 & 0 & 0 & 0 & 0 & 0 \\
\hline 12 & 0 & 1 & 0 & 0 & 0 & 0 & 0 & 1 & 0 & 0 & 0 \\
\hline 13 & 0 & 1 & 1 & 0 & 0 & 0 & 0 & 1 & 1 & 0 & 1 \\
\hline 14 & 0 & 1 & 1 & 0 & 0 & 0 & 0 & 1 & 1 & 0 & 0 \\
\hline 15 & 1 & 0 & 0 & 0 & 0 & 1 & 0 & 1 & 0 & 0 & 1 \\
\hline 16 & 0 & 1 & 1 & 0 & 0 & 0 & 0 & 1 & 1 & 1 & 0 \\
\hline 17 & 0 & 1 & 1 & 1 & 0 & 0 & 0 & 1 & 1 & 0 & 1 \\
\hline 18 & 0 & 1 & 0 & 0 & 0 & 0 & 0 & 1 & 1 & 1 & 0 \\
\hline 19 & 0 & 1 & 1 & 0 & 0 & 0 & 0 & 1 & 1 & 0 & 0 \\
\hline 20 & 0 & 1 & 1 & 1 & 0 & 0 & 0 & 0 & 0 & 0 & 1 \\
\hline 21 & 0 & 1 & 0 & 1 & 1 & 0 & 1 & 0 & 0 & 0 & 1 \\
\hline 22 & 0 & 1 & 0 & 1 & 0 & 0 & 1 & 0 & 0 & 0 & 1 \\
\hline 23 & 0 & 1 & 1 & 0 & 1 & 0 & 0 & 1 & 0 & 0 & 0 \\
\hline 24 & 0 & 1 & 0 & 0 & 0 & 0 & 1 & 1 & 0 & 0 & 0 \\
\hline 25 & 0 & 1 & 0 & 1 & 0 & 0 & 1 & 0 & 0 & 0 & 1 \\
\hline 26 & 0 & 1 & 0 & 0 & 0 & 0 & 0 & 1 & 1 & 0 & 0 \\
\hline 27 & 0 & 1 & 1 & 1 & 0 & 0 & 0 & 1 & 1 & 0 & 1 \\
\hline 28 & 0 & 1 & 1 & 0 & 0 & 0 & 0 & 1 & 1 & 0 & 0 \\
\hline 29 & 0 & 1 & 1 & 0 & 0 & 0 & 0 & 1 & 1 & 1 & 0 \\
\hline 30 & 0 & 1 & 1 & 1 & 0 & 0 & 0 & 1 & 1 & 0 & 1 \\
\hline JML & 2 & 28 & 18 & 10 & 4 & 2 & 5 & 18 & 12 & 4 & 9 \\
\hline
\end{tabular}

Tabel 1. 2 Analisis Data Wawancara

\begin{tabular}{lll}
\hline \multicolumn{1}{c}{ Alasan } & Jumlah & \multicolumn{1}{c}{ Keterangan } \\
\hline Okupansi koridor & 18orang & $\begin{array}{l}60 \% \text { dari pengguna pasar merasa tidak nyaman dengan adanya pedagang yang berada di tengah } \\
\text { koridor pasar. }\end{array}$ \\
\hline Koridor yang sempit & 18orang & $\begin{array}{l}\text { 60\% dari pengguna pasar merasa tidak nyaman karena sempit nya koridor Pasar Tradisional Bandar } \\
\text { Jaya Plaza Lampung Tengah. }\end{array}$ \\
\hline Kurang pencahayaan & 12orang & $40 \%$ dari pengguna pasar merasa tidak nyaman dengan koridor pasar yang kurang pencahayaan. \\
\hline Koridor yang kotor & 10orang & $33,3 \%$ dari pengguna pasar merasa tidak nyaman dengan kondisi koridor pasar yang kotor. \\
\hline Penutup lantai rusak & 4orang & $13 \%$ dari pengguna pasar merasa tidak nyaman karena penutup lantai koridor pasar rusak. \\
\hline Disorientasi sirkulasi & 4orang & $13 \%$ dari pengguna pasar merasa tidak nyaman karena kebingungan arah pada koridor pasar. \\
\hline Penyediaan tong sampah & 9orang & $30 \%$ dari pengguna pasar merasa nyaman jika pada koridor pasar tersedia tong sampah. \\
\hline
\end{tabular}

Metode pengumpulan data kuantitatif dilakukan dengan memberikan kuesioner tertutup. Kuesioner tertutup adalah kuesioner dengan pilihan jawaban yang sudah diberikan oleh peneliti dan responden hanya menentukan jawaban yang sudah diberikan. Kuesioner tertutup ini diberikan kepada 100 orang responden. Metode pengumpulan data ini dilakukan pada tanggal 8 Januari 2019 sampai dengan tanggal 15 Januari 2019. Metode evaluasi tingkat kenyamanan dan kepuasan pengguna koridor menggunakan skala 1 sampai 4 yang bermakna: (1) sangat tidak nyaman/sangat tidak puas; (2) tidak nyaman/tidak puas; (3) nyaman/puas: (4) sangat nyaman/sangat puas. 
Penggunaan skala genap bertujuan untuk memperoleh kecenderungan responden pada suatu kutub (nyaman atau tidak nyaman dan puas atau tidak puas).

\subsection{Metode Analisis Data}

Metode analisis data kualitatif dengan cara mengklasifikasikan jawaban dari 30 orang responden berdasarkan faktor-faktor tingkat kenyamanan responden tersebut. Jawaban-jawaban tersebut berupa tabel hasil kuesioner yang berisi tingkat kenyamanan dan alasan dari responden. Tabel kategorisasi dibuat berdasarkan tabel hasil kuesioner yang ada untuk mengetahui persentase tingkat kenyamanan dan kepuasan responden. Berikut adalah hasil dari kuesioner terbuka yang dilakukan pada pasar tradisional. Analisis data menggunakan analisis isi dari jawaban responden untuk menentukan kata kunci yang dipakai dalam membuat kuesioner tertutup.

Metode analisis data kuantitatif dengan menggunakan analisis distribusi dan ANOVA. Berikut ini adalah penjelasan tentang metode yang akan digunakan.

a. Analisis Distribusi

Hasil pengukuran yang diperoleh disebut data mentah. Besarnya hasil pengukuran yang diperoleh bervariasi. Untuk memperoleh gambaran data yang baik harus diproses untuk menarik kesimpulan. Distribusi adalah daftar nilai data yang disertai dengan nilai frekuensi yang sesuai. Pengelompokan data kedalam beberapa klasifikasi agar ciri-ciri penting data tersebut dapat terlihat. Distribusi akan memberikan gambaran yang tentang perbedaan data.

b. ANOVA (Analysis of Variance)

ANOVA adalah kumpulan dari model statistik yang digunakan untuk menganalisis perbedaan rata-rata antara kelompok dan prosedur terkait. Dalam pengaturan ANOVA, varians diamati pada variabel tertentu dibagi menjadi komponen disebabkan dari sumber variasi. Dalam bentuk yang paling sederhana, ANOVA menyediakan uji statistik apakah rata-rata beberapa kelompok adalah sama, dan adanya generalisasi untuk lebih dari dua kelompok. ANOVA berguna untuk membandingkan (pengujian) tiga atau lebih kelompok atau variabel untuk signifikasi statistik.

\section{Hasil dan Pembahasan}

Hasil penelitian kuesioner atau angket yang ditujukan kepada pedagang dan pembeli yang kemudian dilakukan analisis data temuan hasil penelitian akan dilakukan pembahasan sesuai dengan teori.

\subsection{Distribusi Responden Berdasarkan Jenis Kelamin}

Gambar 3.1a menunjukkan jumlah pengunjung laki-laki lebih rendah daripada pengunjung perempuan, perbedaan yang sangat signifikan ini karena pengunjung laki-laki malas ke pasar, mereka lebih memilih belanja online dari pada harus pergi ke pasar. Kegiatan didalam pasar memang di dominasi oleh pengunjung perempuan yang berbelanja kebutuhan sehari-hari selain itu berbelanja dipasar terbukti dapat memperbaiki suasana hati para perempuan yang kurang baik, oleh karena itu jumlah pengunjung perempuan lebih banyak daripada pengunjung laki-laki.

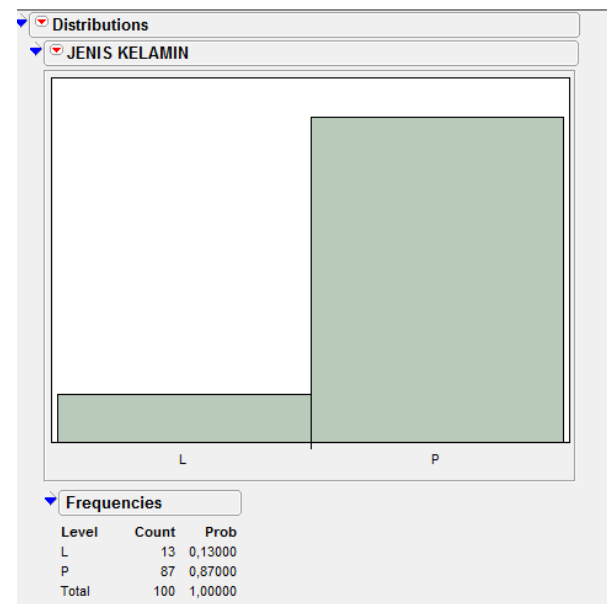

(a)

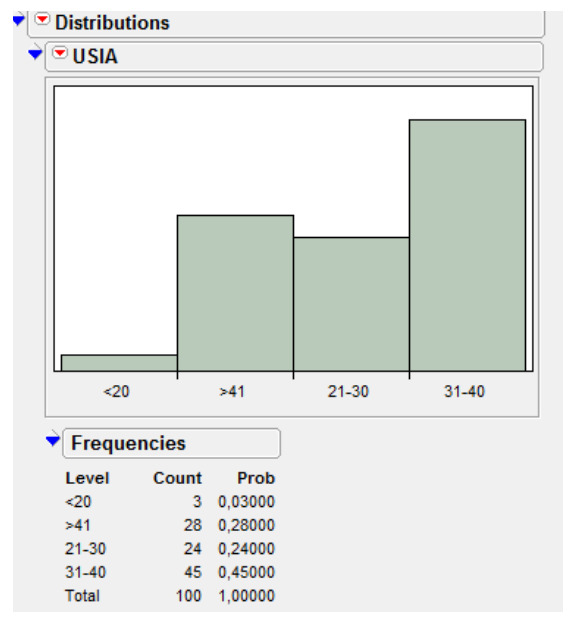

(b)

Gambar 3. 1 Grafik Berdasarkan Jenis Kelamin Responden(a) dan Grafik Distribusi Berdasarkan Usia Responden(b) 


\subsection{Responden Berdasarkan Usia}

Gambar 3.1b menunjukkan jumlah pengunjung berusia 31-40 tahun yang mendominasi didalam pasar. Penyebab pengunjung berusia 31-40 tahun mendominasi pasar adalah pada usia tersebut pengunjung lebih mengerti tentang kebutuhan rumah tangga, mencari harga yang lebih murah dan lebih banyak pilihan daripada membeli di warung. Pengunjung usia kurang dari 20 tahun berada pada tingkat paling rendah. Hal ini disebabkan karena pengunjung usia kurang dari 20 tahun kurang tertarik dengan pasar tradisional dan berasumsi pasar tradisional itu kurang menarik dibandingkan dengan pasar modern.

\subsection{Responden Berdasarkan Pendidikan}

Gambar 3.2 menunjukkan jumlah pengunjung dan pedagang berpendidikan SMA lebih mendominasi dikarenakan di daerah lampung tengah sendiri jika dilihat dari Badan Pusat Statistik Kabupaten Lampung Tengah tingkat pendidikan masyarakat paling banyak adalah SMA. Pengunjung berpendidikan SD paling sedikit jumlahnya karena kebanyakan menjadi pedagang dan bukan menjadi pengunjung.

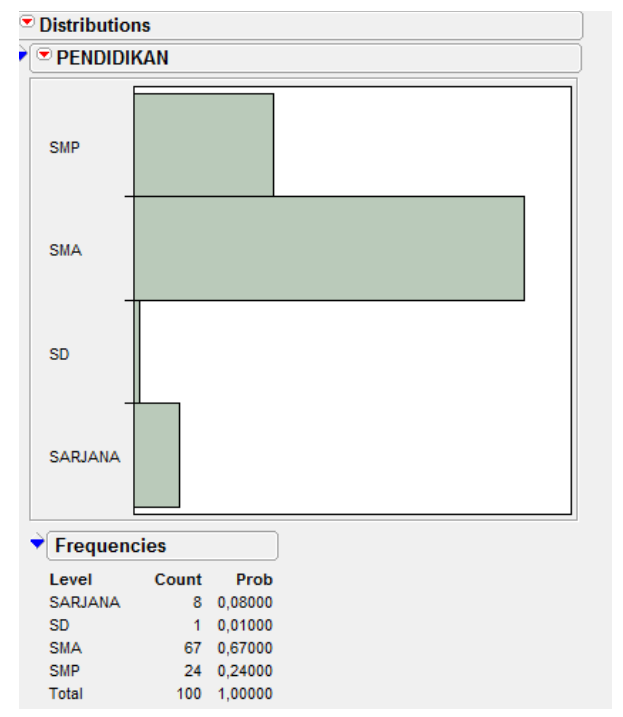

Gambar 3.2 Grafik Pendidikan Responden

\subsection{ANOVA (Analysis of Variance)}

3.4.1 ANOVA Kenyamanan Pengguna Koridor Terhadap Okupansi Koridor Berdasarkan Jenis Kelamin Dan pendidikan Responden.

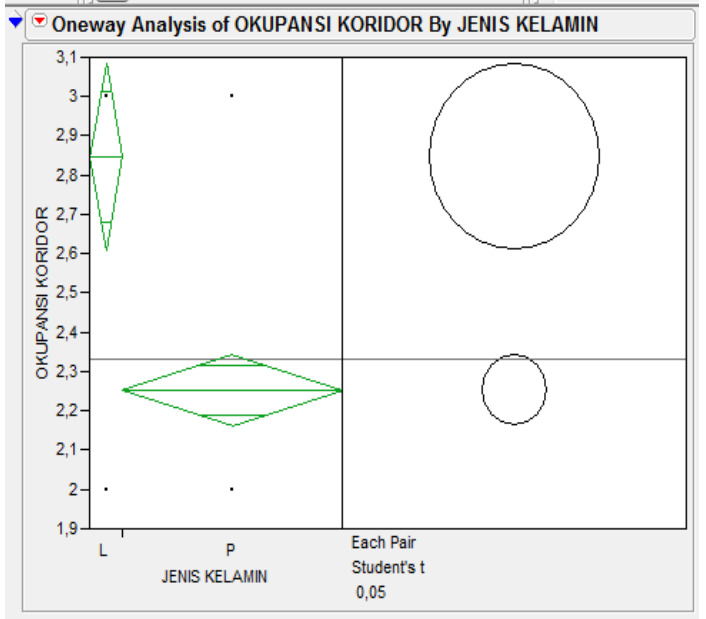

(a)

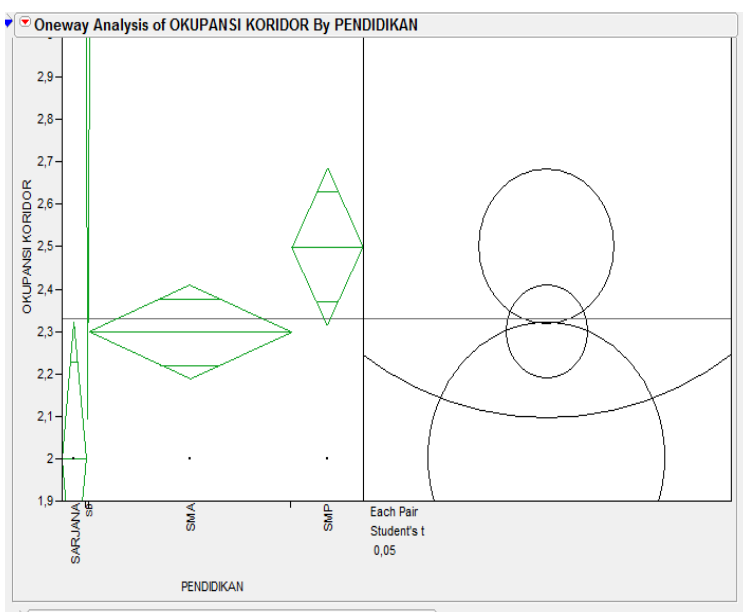

(b)

Gambar 3. 3 Grafik ANOVA kenyamanan pengguna koridor terhadap okupansi koridor Berdasarkan Jenis Kelamin Responden (a) dan Pendidikan Responden (b) 
Gambar 3.3a menunjukkan bahwa kenyamanan pengunjung laki-laki lebih tinggi terhadap okupansi koridor daripada pengunjung perempuan. Hal ini dikarenakan pengguna laki-laki cenderung fokus dengan apa yang ingin dibeli, pengunjung laki-laki berasumsi masih merasa nyaman walaupun ada pedagang di tengah koridor. Berbeda hal nya dengan pengunjung perempuan tidak nyaman dengan adanya pedagang ditengah koridor, karena mengganggu saat pengunjung perempuan berjalan melalui koridor. Penertiban atau penataan lapak dagang dari pelaku okupansi koridor juga dapat dilakukan untuk mengatasi rendahnya tingkat kenyamanan pengunjung perempuan.

Gambar 3.3b menunjukkan bahwa kenyamanan pengunjung berpendidikan SD paling tinggi terhadap okupansi koridor dan pengunjung berpendidikan sarjana paling rendah. Hal ini terjadi karena pemahaman pengunjung berpendidikan SD tentang kenyamanan masih sangat minim dibandingkan dengan pengunjung berpendidikan yang lebih tinggi, menurut mereka adanya okupansi koridor memudahkan mereka membeli barang-barang yang ditawarkan dan tidak harus menuju kios-kios yang ada. Pengunjung berpendidikan sarjana lebih mengerti dan paham tentang okupansi koridor sangat mengganggu pengunjung yang melalui koridor tersebut. Untuk meningkatkan kenyamanan pengguna koridor dapat dilakukan penertiban ataupun penataan lapak dagang dari pelaku okupansi koridor dan memberikan sanksi tegas bila tidak mau ditata ataupun ditertibkan.

ANOVA Kenyamanan Pengguna Koridor Terhadap Pencahayaan Berdasarkan Usia Responden

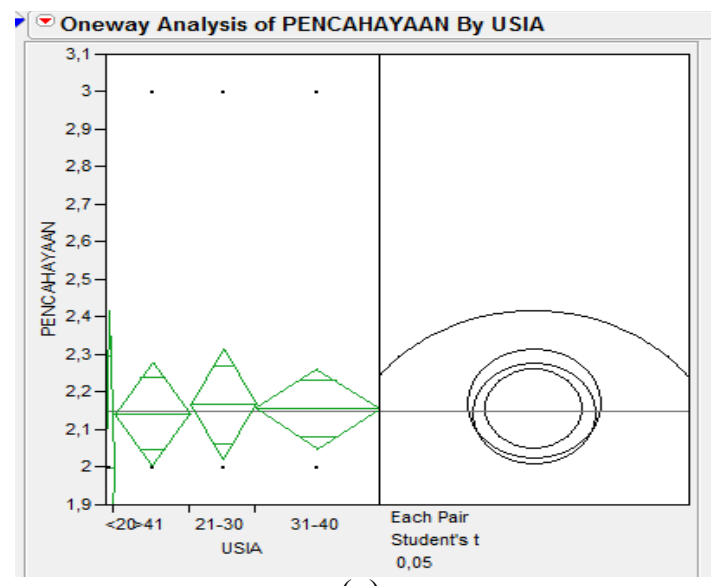

(a)

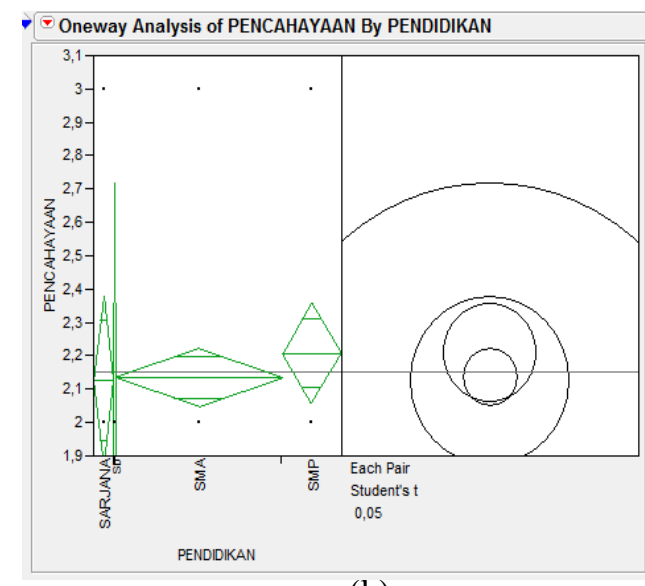

(b)

Gambar 3.6 Grafik ANOVA kenyamanan pengguna koridor terhadap pencahayaan koridor Berdasarkan usia Responden (a) dan Pendidikan Responden (b)

Gambar 3.6a menunjukkan bahwa tingkat kenyamanan pengunjung berusia kurang dari 21-30 tahun yang tertinggi dan tingkat kenyamanan pengunjung berusia kurang dari 20 tahun yang terendah. Semua pengunjung merasa nyaman dengan pencahayaan koridor. Untuk mengatasi kurangnya pencahayaan pada koridor dapat diatasi dengan penggunaan cermin untuk memantulkan cahaya dari luar ke dalam bangunan. Penggunaan bahan cermin lebih hemat energi daripada penggunaan lampu yang menggunakan banyak energi listrik untuk memberikan pencahayaan pada koridor.

Gambar 3.6b menunjukkan bahwa kenyamanan pengguna berpendidikan SMP paling tinggi dan pengguna berpendidikan sarjana paling rendah terhadap pencahayaan. Hal ini karena pengguna berpendidikan SMP adalah pedagang yang setiap hari memang terbiasa dengan pencahayaan yang ada pada saat ini, sedangkan pengguna berpendidikan sarjana adalah pengunjung yang tidak setiap hari berada di pasar tradisional ini. Untuk mengatasi kurangnya pencahayaan pada koridor dapat diatasi dengan penggunaan tubular skylight untuk memantulkan cahaya dari luar ke dalam bangunan. Penggunaan tubular skylight lebih hemat energi daripada penggunaan lampu yang menggunakan banyak energi listrik untuk memberikan pencahayaan pada koridor.

ANOVA kenyamanan pengguna koridor berdasarkan jenis kelamin dapat diambil kesimpulan bahwa tingkat kenyamanan dan kepuasan pengguna laki laki dan perempuan rendah karena adanya okupansi koridor oleh pedagang buah yang tidak ditertibkan, kurangnya penghawaan dan pencahayaan pada koridor pasar, tersumbatnya air kotor yang menyebabkan bau yang tidak sedap pada koridor pasar basah, penutup lantai terkelupas, ketiadaan tong sampah pada koridor dan ketiadaan papan informasi penunjuk arah yang menyulitkan pengguna pada saat akan keluar dari pasar tersebut.

ANOVA kenyamanan pengguna koridor berdasarkan usia dapat diambil kesimpulan bahwa pengguna koridor yang berusia kurang dari 20 tahun paling rendah tingkat kenyamanan dan kepuasannya, karena menurut mereka pasar tidak menarik. Pengguna koridor yang berusia 31-40 tahun memiliki tingkat kenyamanan yang cukup tinggi 
dibandingkan dengan pengguna koridor yang lain, walaupun dalam kenyataan nya mereka merasa tidak nyaman dengan keadaan koridor pada saat ini, terutama permasalahan tentang okupansi koridor dan pencahayaan pada koridor. Kepuasan terhadap fasilitas pendukung juga sangat rendah karena ketiadaan papan informasi yang menyebabkan pengguna koridor kebingungan saat akan keluar dari pasar. Ketiadaan tong sampah pada koridor berpengaruh terhadap kebersihan koridor, penutup lantai yang terkelupas yang belum diperbaiki ini juga mengakibatkan rendahnya kepuasan pengguna koridor. Saluran air kotor yang tersumbat menyebabkan bau yang tidak sedap karena air dari kios daging dan ikan tidak mengalir keluar pasar.

ANOVA kenyamanan dan kepuasan pengguna koridor berdasarkan pendidikan dapat diambil kesimpulan bahwa pengguna koridor yang berpendidikan sarjana rendah tingkat kenyamanan dan kepuasannya pada semua indikator yang ada, sedangkan pengguna koridor yang berpendidikan SMA lebih tinggi tingkat kepuasannya, walaupun mereka juga kurang nyaman dan kurang puas. Perlu adanya perbaikan-perbaikan pada saluran air kotor, penutup lantai dan penertiban atau penataan lapak dari pelaku okupansi koridor. Penggunaan tubular skylight untuk mengatasi kurang pencahayaan pada koridor pasar. Untuk meningkatkan kepuasan pengguna koridor dapat dilakukan dengan pengadaan tong sampah dan pengadaan papan informasi penunjuk arah.

\section{Kesimpulan}

Kesimpulan yang dapat diambil dari penelitian yang dilakukan adalah tingkat kenyamanan dan kepuasan pengunjung memiliki tingkat yang rendah, hal ini disebabkan oleh beberapa faktor. Faktor yang paling berpengaruh pada tingkat kenyamanan koridor pada pasar tradisional Bandar Jaya Plaza Lampung Tengah adalah adanya okupansi atau penguasaan koridor utama untuk area berjualan dengan nilai rata-rata tingkat kenyamanan sebesar 2,3 dari nilai maksimal 4. Kurangnya pencahayaan pada koridor dengan nilai rata-rata kenyamanan sebesar 2,1 dari nilai maksimal 4. Kurang bersihnya koridor dengan nilai rata-rata sebesar 2,1 dari nilai maksimal 4. Tingkat kepuasan pengguna koridor terhadap saluran air kotor dengan nilai rata-rata sebesar 2,1 dari nilai maksimal 4. Tingkat kepuasan pengguna koridor terhadap ketiadaan tong sampah dengan nilai rata-rata sebesar 1,6 dari nilai maksimal 4. Tingkat kepuasan pengguna koridor terhadap ketiadaan papan informasi penunjuk arah dengan nilai rata-rata 1,4 dari nilai maksimal 4. Pengguna koridor sudah merasa cukup nyaman dengan koridor pasar tetapi belum puas dengan fasilitas-fasilitas penunjang koridor pada pasar tersebut.

\section{Daftar Pustaka}

Peraturan Presiden Republik Indonesia Nomor 112 Tahun 2007. Penataan dan Pembinaan Pasar Tradisional.

Creswell, J. W. (2003). Qualitative, quantitative, and mixed methods approaches.

Badan Pusat Statistik Lampung Tengah, 2016. Penduduk Berumur 15 Tahun Keatas Menurut Tingkat Pendidikan Yang Ditamatkan Dan Jenis Kelamin Di Lampung Tengah. Lampung Tengah: Badan pusat Statistik Jakarta: Penerbit Erlangga. 2008.

Gallion, Arthut B dan Eisner, Simon. 1986. The Urban Pattern: City Planning Design, Fifth Edition.

Hakim, R. dan H. Utomo. 2003. Komponen Perancangan Arsitektur Lanskap. Jakarta: Bumi Aksara.

Kamus Besar Bahasa Indonesia. 1996. Definisi Pasar Tradisional. Jakarta: Depdikbud.

McCormick, E. J. dan M. S. Sanders. 1987. Human Factor in Engineering and Design. McGraw-Hill Chong Moh, Ltd., Singapura.

Mankiew, N. Gregory. 2007. Makro Ekonomi, Edisi ke-6. Jakarta: Erlangga.

Mujiyana \& Elisa, Ingge. (2013). Analisis Faktor-Faktor yang Mempengaruhi Keputusan Pembelian Via Internet Pada Toko Online. Universitas Gunadarma.

Nazir, Moh. (2013). Metode Penelitian. Bogor: Ghalia Indonesia. Peraturan Menteri Perdagangan Republik Indonesia Nomor 70/M-DAG/PER/12/2013, Pedoman Penataan dan Pembinaan Pasar Tradisional Pusat Perbelanjaan dan Toko Modern. Menteri Perdagangan Republik Indonesia.

Peraturan Presiden Republik Indonesia Nomor 112 Tahun 2007, Penataan dan Pembinaan Pasar Tradisional Pusat Perbelanjaan dan Toko Modern.

Sadillah, Emiliana dkk, 2011, Eksistensi Pasar Tradisional, Yogyakarta: Balai

Satwiko. 2009. Pengertian Kenyamanan Dalam Suatu Bangunan. Yogyakarta: Wignjosoebroto.

Sinaga Pariaman. 2004. Pasar Modern VS Pasar Tradisional. Jakarta: K

ementerian Koperasi dan UKM. 